\title{
Pengaruh City Branding terhadap Image Of Urban Destination dan Dampaknya pada Post-Visit Behavior
}

\author{
Juanim \\ Fakultas Ekonomi Universitas Pasundan Bandung \\ Jl. Taman Sari No. 6-8 Bandung 40116 \\ E-Mail: juanim@unpas.ac.id \\ Neng Lilis Rahmawati \\ Fakultas Ekonomi Universitas Pasundan Bandung \\ J1. Taman Sari No. 6-8 Bandung 40116 \\ E-Mail: n_lilisrahmawati@yahoo.com
}

\begin{abstract}
The purpose of this study is to know the phenomenon and get empirical evidence, and also conclusion about the influence of city branding on image of urban destination and it impact on post-visit tourist behavior to Bandung city. This research using descriptive and verificative methods. The sampling technique is sampling incidental. The research surveyed 100 respondents. Data analysis method of this research using path analysis. The result of this reveals that, City branding of Bandung as a creative city in the high category, Image of urban destination in the high category, Post-visit behavior in the high category, and the influence of city branding on image of urban destination and it impact on post-visit tourist behavior to Bandung city by 33,1\%.
\end{abstract}

Keywords: city branding, image of urban destination, post-visit behavior, Bandung.

\begin{abstract}
ABSTRAK
Tujuan penelitian ini adalah untuk mengetahui fenomena dan mendapatkan bukti empiris, juga kesimpulan mengenai pengaruh city branding terhadap image of urban destination dan dampaknya pada post-visit behavior wisatawan ke Kota Bandung. Penelitian ini menggunakan metode deskriptif dan verifikatif. teknik sampling yang di gunakan adalah sampling kebetulan. Penelitian ini melakukan survei terhadap 100 responden. Metode analisis data pada penelitian ini menggunakan analisis jalur. Hasil pada penelitian ini mengungkapkan bahwa city branding kota Bandung adalah sebagai kota kreatif pada kategori baik, citra kota sebagai urban destination pada kategori baik, perilaku pasca berkunjung pada kategori baik, dan pengaruh city branding terhadap citra kota sebagai urban destination dan perilaku pasca berkunjung wisatawan ke kota Bandung sebesar 33,1\%.
\end{abstract}

Kata Kunci: city branding, image of urban destination, perilaku pasca berkunjung, Bandung. 


\section{PENDAHULUAN}

Daya saing sebuah wilayah saat ini telah menjadi perhatian para ilmuwan termasuk di dalamnya terkait pemasaran dan branding. Cara terbaik untuk mendorong daya saing antar daerah salah satunya menciptakan merek yang kuat dengan mencerminkan identitas daerah guna menarik konsumen potensial, wisatawan, investor, ataupun penduduk, oleh karenanya brand merupakan pembeda yang jelas menjadi ujung tombak bagi daya saing suatu kota. Tujuan dari adanya branding untuk meningkatkan hubungan investasi bisnis, meningkatkan posisi kompetitif pasar pariwisata, mempromosikan pembangunan ekonomi dan sosial secara umum, dan mendorong masyarakat untuk mengidentifikasi tempat tinggal mereka. Kota membutuhkan suatu identitas yang membedakan kota satu dengan kota lainnya melalui sebuah brand yang di mana brand merupakan sebuah identitas berupa nama, logo, tanda, desain, dan kombinasi seluruhnya. Cavia Fernandez et al. (2013) menjelaskan branding tidak dipandang sebagai cara untuk mengelola suatu kota, melainkan dipandang sebagai alat untuk menyampaikan citra positif yang bertujuan untuk meningkatkan persepsi yang dimiliki oleh berbagai pemangku kepentingan, di mana branding tidak dapat merubah suatu kota tetapi dapat membantu meningkatkan daya saing secara keseluruhan. Jika city branding mampu membentuk citra positif dibenak wisatawan maka akan mempengaruhi cara perilaku wisatawan sebelum, sesudah, dan setelah mengunjungi suatu destinasi. Menurut Aaker (2012) mengemukakan merek yang kuat dapat membentuk sebuah citra, hal ini diperkuat oleh Kavaratzis dan Ashworth (2005) yang mengemukakan bahwa membentuk city branding dapat mempengaruhi peta mental dengan kata lain bagaimana pengunjung mempersepsikan sebuah kota dibenak mereka.

City branding merupakan cara memposisikan kota dalam ketatnya persaingan global yang kuat sebagai tanggapan terhadap dinamika ekonomi, politik, dan sosial (Kavaratzis dan Ashworth, 2007). Sedangkan menurut Anholt (2010) branding adalah proses mendesain, merencanakan, dan mengkomunikasikan nama dan identitas dengan tujuan untuk membangun atau mengelola reputasi. City branding diyakini memiliki kekuatan untuk merubah persepsi seseorang terhadap suatu kota atau bertujuan untuk melihat perbedaan potensi suatu kota dengan kota lainnya.

Kriteria yang mendasari penilaian dalam city branding yaitu pertama sebagai attributes yaitu mampu menggambarkan sebuah karakter, daya tarik, gaya, dan personalitas kota dan kedua sebagai message yaitu menggambarkan sebuah cerita secara pintar, menyenangkan, dan mudah atau selalu diingat, kemudian sebagai differentiation dan ambassadorship yaitu memberikan kesan unik, berbeda dari kota lain dan menginspirasi orang untuk datang dan ingin tinggal di kota tersebut (Yuli, 2011). Tujuan city branding menurut Handito (2009) yaitu memperkenalkan kota/ daerah lebih dalam, memperbaiki citra, menarik wisatawan asing dan domestik, menarik minat investor untuk berinvestasi, dan meningkatkan perdagangan.

Kota Bandung perlu melakukan revitalisasi identitasnya dengan mengangkat potensi yang dimilikinya, agar lebih dikenal dan mengundang para pemangku kepentingan untuk datang ke kota Bandung. Oleh karena itu kota Bandung harus menyegerakan penetapan brand yang pasti untuk memperbaiki citra negatif yang akan membawa kerugian bagi kota Bandung sendiri. Hal ini terlihat pada pra penelitian terhadap masyarakat bahwa citra kota Bandung masih adanya permasalahan seperti kemacetan, sampah, dan kesemrawutan. Jika permasalahan ini tidak diperbaiki maka akan berdampak negatif bagi keberlangsungan kehidupan kota Bandung, baik itu perekonomian, sosial, pariwisata, dan lainnya yang mengakibatkan kota Bandung tidak dilirik lagi oleh audiens eksternal termasuk wisatawan. Dengan menyegerakan penetapan brand bagi kota Bandung yang didasarkan pada identitas kota sebagai kota kreatif karena masyarakat kota Bandung yang merupakan sumber daya manusia kreatif sehingga menjadi aset untuk membangun kota Bandung menjadi lebih baik.

Hal tersebut akan membawa pengaruh pada wisatawan yang berkunjung ke kota Bandung, sehingga mereka akan menjadi media komunikasi antara kota Bandung dengan target pasarnya, melalui kepuasan yang wisatawan rasakan, kemudian mereka akan merekomendasikan pada orang lain dan kecenderungan mengunjungi kembali kota Bandung. Pernyataan tersebut sesuai dengan yang dikemukakan oleh Chon's (2013) mengungkapkan bahwa citra destinasi berperan dan berpengaruh dalam perilaku pembelian dan kepuasan. Kemudian dijelaskan pula 
oleh Coshall (2013) menyatakan bahwa citra destinasi merupakan kesan wisatawan secara umum terhadap suatu destinasi wisata. Begitupun menurut Echtner dan Ritchie (2013) yang mengungkapkan bahwa citra destinasi berperan penting dalam memahami perilaku wisatawan dalam melakukan perjalanan.

Citra dari suatu destinasi merupakan bagian penting untuk dijual pada pemangku kepentingan termasuk wisatawan. Fakeye dan Crompton (2007) menyatakan bahwa citra destinasi merupakan gambaran pikiran, kepercayaan, perasaan, dan persepsi terhadap suatu destinasi. Sedangkan menurut Echtner dan Ritchie (2003) citra destinasi adalah persepsi dari wisatawan potensial terhadap suatu destinasi. Menurut Echtner dan Ritchie (2003) pula, citra destinasi adalah persepsi terhadap kombinasi kompleks dari berbagai produk dan atribut yang terkait.

Citra destinasi dibentuk dari primary image dan secondary image, yaitu bahwa primary image berasal dari setelah wisawatan berkunjung ke destinasi tersebut dan persepsi dibangun kembali melalui pengalaman ketika berada di suatu destinasi (Phelps, 2011). Sedangkan secondary image menurut Gunn dan Mansfeld (2011) dibangun sebelum berkunjung ke suatu destinasi, yaitu 1) Organic/informal image berasal dari sumber informasi secara umum seperti pengalaman pribadi, pendapat teman atau word of mouth reports, media massa, dan informasi lainnya. Sumber informasi ini tidak dapat dikontrol oleh pemasar (pengelola destinasi terkait). 2) Induced/ formal image yang dirancang oleh pemasar dari suatu destinasi yang bertujuan membentuk citra sesuai dengan harapan pemasar. Bentuk dari sumber informasi tersebut adalah berbagai iklan, kegiatan, festival, dan fenomena alam yang diperkenalkan oleh pemasar untuk menarik wisatawan agar datang ke destinasi tersebut.

Echtner dan Ritchie (2003) menyatakan bahwa proses pembentukan citra destinasi terdapat dua hal penting yaitu pertama, seseorang dapat memiliki citra destinasi walaupun belum pernah mengunjungi objek tersebut karena destinasi tersebut sudah terkenal melalui berbagai media informasi yang diterimanya dan kedua, seseorang mengalami perubahan pada citra destinasi sebelum dan setelah seseorang melakukan kunjungan ke suatu destinasi

Perilaku pasca berkunjung merupakan tindakan seseorang dari hasil evaluasi selama melakukan perjalanan kunjungan ke suatu destinasi. Dalam penelitian ini perilaku pasca berkunjung diadopsi dari perilaku pasca pembelian yang merupakan bagian dari proses keputusan pembelian. Menurut Kotler dan Keller (2012) perilaku konsumen merupakan sebuah pembelajaran bagaimana individu-individu, kelompok-kelompok, dan organisasi-organisasi memilih, membeli, menggunakan, dan membuang barang, jasa, ide, atau pengalaman untuk memenuhi kebutuhan dan keinginan mereka. Sedangkan perilaku wisatawan menurut Ryan et al. (2007) mengemukakan bahwa perilaku wisatawan dibagi menjadi tiga tahap meliputi pengambilan keputusan sebelum berkunjung, pengalaman di lokasi destinasi, kemudian evaluasi pengalaman dan minat perilaku pasca kunjungan.

Berdasarkan penjelasan tersebut mengindikasikan bahwa citra destinasi memiliki pengaruh pada perilaku wisatawan yaitu mempengaruhi proses pengambilan keputusan pilihan tujuan menyangkut pengalaman selama perjalanan bagaimana kualitas perjalanan selama tinggal di suatu destinasi, nilai dan kepuasan secara keseluruhan, dan niat mengunjungi dan kesediaan untuk merekomendasikannya pada orang lain (Chen dan Tsai, 2007). Kota yang memiliki citra destinasi positif akan menyebabkan tingkat kepuasan lebih besar dan berpotensi pada minat perilaku wisatawan terhadap destinasinya.

Hal ini dipertegas oleh Theodhori dan Quirici (2014) dalam penelitiannya mempromosikan nation branding bertujuan untuk meningkatkan citra yang membedakan dirinya dari para pesaing karena globalisasi serta memiliki dampak yang besar terhadap perilaku wisatawan untuk mengeksplorasi destinasi. Sebuah daerah saat ini mencoba mengembangkan berbagai identitas wilayahnya, oleh karena itu tujuan penelitian ini untuk mengkaji pengaruh city branding terhadap image of urban destination dan dampaknya pada post-visit behavior wisatawan.

\section{METODE}

\section{Rancangan Penelitian}

Metode yang digunakan dalam penelitian ini adalah metode deskriptif dan verifikatif, sedangkan tipe hubungan antara variabel yang digunakan dalam penelitian ini adalah asosiatif kausalitas yaitu menguji hubungan sebab akibat antar variabel. Dalam penelitian ini terdapat tiga jenis variabel yaitu variabel independen, intervening dan variabel dependen. 
Analisa deskriptif digunakan untuk menjawab penelitian yang bersifat rumusan deskriftif dengan melihat gambaran secara mandiri masing-masing variabel. Analisa verifikatif digunakan untuk menguji hipotesis penelitian yang menjelaskan apakah ada tidaknya hubungan kausalitas antar variabel.

\section{Populasi dan Sampel}

Populasi dalam penelitian ini adalah seluruh wisatawan Kota Bandung baik wisatawan lokal maupun mancanegara. Penetapan jumlah populasi diambil dari data wisatawan Kota Bandung pada tahun 2013 yaitu sebanyak 3.897.429. Teknik Sampling yang digunakan adalah random sampling. Berdasarkan rumus slovin dengan derajat kesalahan $10 \%$, maka ukuran sampel sebanyak 100 responden.

\section{Pengembangan Instrumen Penelitian}

Instrumen penelitian dikembangkan berdasarkan pada berbagai teori yang dikembangkan dari beberapa penelitian sebelumnya yang terkait dengan variabel dalam penelitian ini. Tabel 1. adalah operasionalisasi variabel yang digunakan untuk mengembangan instrumen penelitian. Instrumen dikembangankan dengan mengunakan penedekatan skala Interval (simantik diferensial).

\section{Teknik Pengumpulan Data}

Teknik pengumpulan data yang digunakan dalam penelitian mengunakan tiga penedekatan yaitu observasi, wawancara, dan kuesioner. Sumber data yang digunakan dalam penelitian ini merupakan data primer dan data sekunder. Secara khusus, data primer dikumpulkan oleh peneliti berdasarkan wawancara dan kuesioner yang dibagikan kepada responden yang menjadi sampel dalam penelitian ini. Data sekunder dalam penelitian ini dikumpulkan dari studi literatur, dokumentasi dan laporan-laporan yang terkait dengan objek penelitian.

\section{Teknik Analisis Data}

Teknik analisis data dalam penelitian ini digunakan untuk menguji hipotesis penelitian adalah Path Analysis, yaitu metode statistik bagian dari regresi yang dapat digunakan untuk menganalisis hubungan sebab akibat antar satu variabel dengan variabel lainnya. Metode ini digunakan untuk menganalisis pola hubungan antar variabel dengan tujuan untuk mengetahui pengaruh langsung ataupun tidak langsung (Juanim, 2004). Adapun diagram jalur yang menyatakan adanya pengaruh antara variabel eksogen terhadap variabel endogen seperti yang terlihat pada Gambar 1.

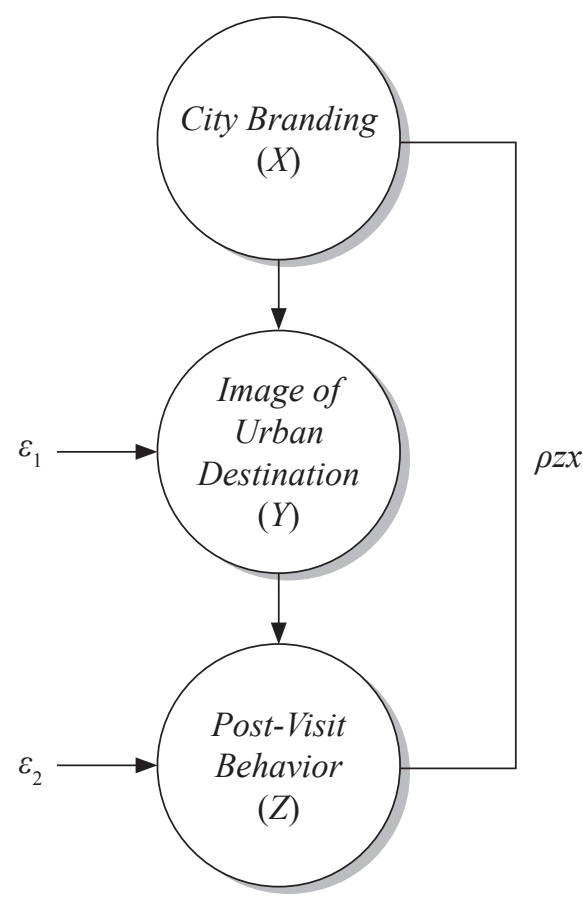

Gambar 1. Diagram Analisis Jalur

Adapun persamaan Struktural dari diagram jalur adalah sebagai berikut:

$Y=\rho_{y x} X+\varepsilon_{1}$

$\mathrm{Z}=\rho_{z y} Y+\rho_{z x} X+\varepsilon_{2}$

\section{HASIL}

\section{Hasil Analisis Verifikatif}

Hasil Pengolahan hasil pengujian verifikatif pengaruh variabel city branding terhadap image of urban destination dan post-visit behavior dengan menggunakan SPSS diketahui bahwa model yang digunakan pada penelitian ini adalah cukup fit dengan dengan hasil observasi. Adapun berdasarkan paradigma penelitian persamaan struktural model matematis sebagai berikut:

Struktural $1 Y=0,637 X+\varepsilon_{1}$

Struktural $2 Z=0,520 Y+0,584 X+\varepsilon_{2}$ 
Tabel 1. Operasionalisasi Variabel Penelitian

\begin{tabular}{|c|c|c|}
\hline Variabel & Dimensi & Indikator \\
\hline \multirow{10}{*}{$\begin{array}{l}\text { City branding } \\
(X)\end{array}$} & Presence & Keberadaan city branding \\
\hline & \multirow[t]{2}{*}{ Place } & Bangunan kota \\
\hline & & Taman kota \\
\hline & \multirow[t]{2}{*}{ People } & Kreatifitas masyarakat kota \\
\hline & & Komunitas masyarakat kota \\
\hline & \multirow[t]{2}{*}{ Pre-requiest } & Keberagaman objek wisata \\
\hline & & Kemudahan menjangkau objek wisata \\
\hline & \multirow[t]{2}{*}{ pulse } & Daya tarik objek wisata \\
\hline & & Atraksi wisata yang menampilkan hal baru \\
\hline & Potential & Kemampuan kreatifitas kota Bandung menjadi kota kreatif se-Indonesia \\
\hline \multirow{7}{*}{$\begin{array}{l}\text { Image of urban } \\
\text { destination }(Y)\end{array}$} & \multirow[t]{2}{*}{ Cognitive image } & Kualitas infrastruktur \\
\hline & & Kemenarikan objek wisata \\
\hline & \multirow[t]{3}{*}{ Unique image } & Keunikan produk \\
\hline & & Keunikan atraksi wisata \\
\hline & & Keunikan letak kota \\
\hline & \multirow[t]{2}{*}{ Affective image } & Besarnya semangat berkunjung \\
\hline & & Kenyamanan lingkunga \\
\hline \multirow{12}{*}{$\begin{array}{l}\text { Post visit behavior } \\
\text { (Z) }\end{array}$} & \multirow[t]{4}{*}{ Post visit satisfaction } & Kepuasan mengunjungi objek wisata kota \\
\hline & & Kepuasan menggunakan transportasi lokal kota \\
\hline & & Kepuasan menggunakan produk khas Bandung \\
\hline & & Kepuasan menggunakan penginapan yang berada di kota \\
\hline & \multirow[t]{4}{*}{ Post visit action } & Kesediaan merekomendasikan objek wisata yang dikunjungi \\
\hline & & Kesediaan merekondasikan menggunakan transportasi lokal kota Bandung \\
\hline & & Kesediaan merekomendasikan produk atau souvenir khas \\
\hline & & Kesediaan untuk merekomendasikan penginapan yang berada di kota \\
\hline & \multirow[t]{4}{*}{ Post visit uses and disposal } & Keinginan untuk kembali datang \\
\hline & & Keinginan kembali untuk menggunakan transportasi lokal \\
\hline & & Keinginan kembali membeli produk atau souvenir khas kota \\
\hline & & Keinginan kembali untuk menggunakan penginapan yang berada di kota \\
\hline
\end{tabular}

Persamaan struktural 1 menggambarkan pengaruh city branding terhadap image of urban destination dan dampaknya pada post-visit behavior. Berdasarkan hasil analisis di peroleh bahwa nilai koefisien beta variabel city branding adalah sebesar 0,637 , diperoleh nilai $\mathrm{t}_{\text {hitung }}$ sebesar 8,189 dengan mengambil taraf signifikan $\alpha$ sebesar 5\%, maka nilai $t_{\text {tabel }}$ sebesar 1,980 , sehingga $\mathrm{t}_{\text {hitung }}>\mathrm{t}_{\text {tabel }}$ atau 8,189 $>1.980$, maka menolak $\mathrm{H}_{0}$ atau dengan kata lain city branding berpengaruh terhadap image of urban destination sebesar 0,637 . Sedangkan besarnya kontribusi city branding (X) secara langsung mempengaruhi image of urban destination adalah 0,406 . Hasil ini peroleh dari hasil pengolahan data nilai koefisien determinasi (R-square). Hal tersebut 
menggambarkan bahwa kontribusi variabel X (city branding) Bandung terhadap naik turunnya variabel $\mathrm{Y}$ (image of urban destination) sebesar $40,6 \%$ dan sisanya 59,4\% merupakan kontribusi dari variabel lain selain variabel yang digunakan dalam penelitian ini.

Sedangkan Persamaan struktural 2 mengambarkan pengaruh city branding dan image of urban destination terhadap post-visit behavior. Nilai koefisien beta variabel X (city branding) terhadap post-visit behavior adalah sebesar 0,584, dan pengaruh image of urban destination terhadap post-visit behavior adalah 0.520. Sedangkan hasil pengujian diperoleh nilai $t_{\text {hitung }}$ sebesar 7,131 dengan mengambil taraf signifikan $\alpha$ sebesar $5 \%$, maka nilai $\mathrm{t}_{\text {tabel }}$ sebesar 1,980 , sehingga $\mathrm{t}_{\text {hitung }}>\mathrm{t}_{\text {tabel }}$ atau $7,131>1.980$, maka menolak $\mathrm{H}_{0}$ atau dengan kata lain city branding berpengaruh terhadap post-visit behavior sebesar 0,584. Dan untuk pengaruh image of urban destination terhadap post-visit behavior diperoleh nilai $\mathrm{t}_{\text {hitung }}$ sebesar 6,021 dengan mengambil taraf signifikan $\alpha$ sebesar $5 \%$, maka nilai $t_{\text {tabel }}$ sebesar 1,980 , sehingga $t_{\text {hitung }}$ $>\mathrm{t}_{\text {tabel }}$ atau $6,021>1.980$, maka menolak $\mathrm{H}_{0}$ atau dengan kata lain image of urban destination berpengaruh terhadap post-visit behavior sebesar 0,520.

Disamping analisis pengaruh langsung berikut juga disajikan hasil analisis pengaruh tidak langsung. Berdasarkan hasil perhitungan nilai korelasi dan kefisien jalur yang dilakukan dengan SPSS dapat diketahui besarnya pengaruh langsung dan tidak langsung city branding terhadap post-visit behavior melalui image of urban destination dapat dilihat pada Tabel 2.

Berdasarkan pada hasil pengolahan dapat dijelaskan bahwa terdapat pengaruh yang postif dan signifikan secara tidak langsung city branding terhadap post-visit behavior melalui image of urban destination. Secara keseluruhan hasil analisis verifikatif dapat digambarkan melalui model analisis jalur pada Gambar 2.

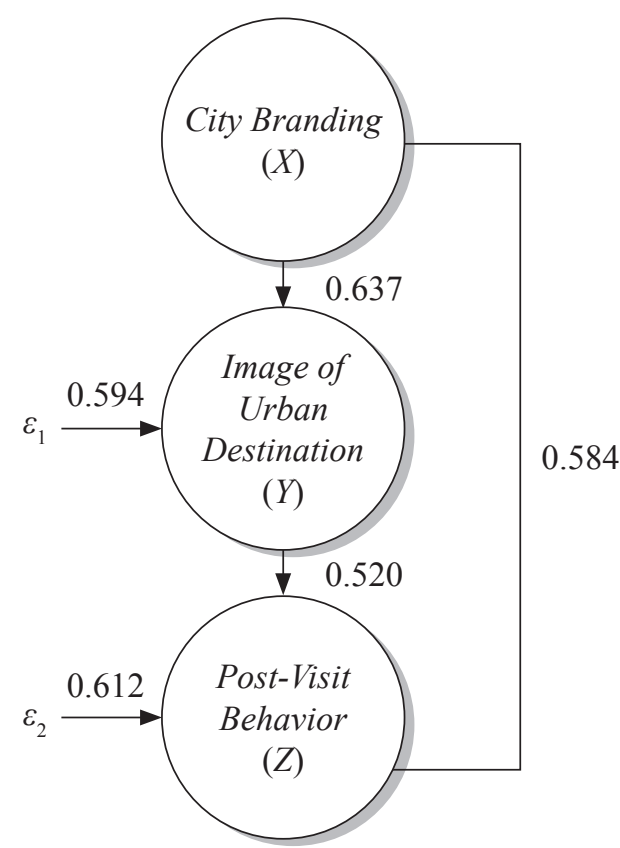

Gambar 2. Diagram Jalur Keseluruhan

Hasil analisis deskriptif menunjukkan bahwa secara umum city branding dalam katagori baik. Hal ini terlihat pada indeks rata-rata city branding yakni 3,742 termasuk dalam katagori kriteria tinggi. Maka dapat disimpulkan bahwa branding untuk kota Bandung sebagai kota kreatif di anggap pantas oleh wisatawan yang berarti kota Bandung memiliki potensi kreatifitas yang tinggi, baik itu dari segi desain taman dan bangunannya, masyarakat kota Bandung, keberagaman objek wisata yang mencerminkan identitas kota bandung sebagai kota kreatif, terutama kota Bandung sempat menjadi pilot project kota kreatif se-Asia Timur pada tahun 2007 dalam pertemuan internasional kota berbasis ekonomi kreatif yang diikuti 11 negara di Yokohama Jepang. Begitu juga image of urban destination dengan indeks rata-rata 3,87 yang menunjukkan pada katagori baik.

Tabel 2. Pengaruh Langsung dan Pengaruh Tidak Langsung City Branding terhadap Post-Visit Behavior melalui Image of Urban Destination

\begin{tabular}{lcc}
\hline \multicolumn{1}{c}{ Kausalitas } & Pengaruh \\
\cline { 2 - 3 } & Langsung & Tidak Langsung \\
\hline Pengaruh city branding terhadap image of urban destination & 0,637 & - \\
Pengaruh image of urban destination terhadap post-visit behavior & 0,520 & - \\
Pengaruh city branding terhadap post-visit behavior & 0,584 \\
$\begin{array}{l}\text { Pengaruh tidak langsung city branding post-visit behavior melaui image of urban } \\
\text { destination }\end{array}$ & $(0,637)(0,520)=0,33124$ \\
\hline
\end{tabular}

Sumber: Hasil Pengolahan Data, 2014 


\section{PEMBAHASAN}

Hasil analisis deskriptif menunjukkan bahwa secara umum city branding dalam katagori baik. Hal ini terlihat pada indeks rata-rata city branding yaitu 3,742 termasuk dalam katagori kriteria tinggi. Maka dapat disimpulkan bahwa branding untuk kota Bandung sebagai kota kreatif dianggap pantas oleh wisatawan yang berarti kota Bandung memiliki potensi kreatifitas yang tinggi, baik itu dari segi desain taman dan bangunannya, masyarakat kota Bandung, keberagaman objek wisata yang mencerminkan identitas kota bandung sebagai kota kreatif, terutama kota Bandung sempat menjadi pilot project kota kreatif se-Asia Timur pada tahun 2007 dalam pertemuan internasional kota berbasis ekonomi kreatif yang diikuti 11 negara di Yokohama Jepang. Begitu juga image of urban destination dengan indeks rata-rata 3,87 yang menunjukkan pada katagori baik.

Image of urban destination dipersepsikan oleh wisatawan secara keseluruhan dianggap menunjukkan hal yang baik, namun tanggapan wisatawan terhadap indikator mengenai kualitas infrastruktur di kota Bandung belum menunjukkan hal yang baik atau dapat diartikan bahwa masih perlu adanya perbaikan dan peningkatan infrastruktur, karena hal tersebut merupakan kebutuhan dasar untuk menunjang kegiatan masyarakat.

Post-visit behavior wisatawan yang datang ke kota Bandung menunjukkan indeks rata-rata sebesar 3,55. Hal ini mengindikasikan masih dalam katagori baik, karena secara umum wisatawan merasa puas, bersedia untuk merekomendasikan, dan berkeinginan kembali berkunjung ke kota Bandung. Namun wisatawan memiliki tanggapan yang kurang baik terhadap penggunaan transportasi lokal. Maka hal ini dapat mempengaruhi image kota Bandung menjadi kurang baik, karena wisatawan merupakan aset bagi kota Bandung dimana mereka merupakan bagian pemasaran yang akan merekomendasikan kota Bandung pada orang lain, dan kecenderungan wisatawan untuk datang kembali ke kota Bandung. Dari kurang baiknya tanggapan wisatawan terhadap transportasi lokal kota Bandung membuktikan bahwa kemacetan menjadi akibatnya sehingga wisatawan lebih memilih menggunakan mobil pribadi untuk mengunjungi setiap destinasi wisata di kota Bandung. Pada dasarnya jika perilaku pasca berkunjung wisatawan kurang baik maka image kota
Bandung pun akan menjadi kurang baik. Untuk itu adanya city branding guna mengangkat reputasi kota Bandung agar dapat melawan image yang kurang baik dan merubah image tersebut menjadi lebih baik, kemudian wisawatan yang telah berkunjung akan merekomendasikan kota Bandung sebagai tujuan wisata pada orang lain dan kecenderungan untuk berkunjung kembali ke kota Bandung.

City branding tidak hanya untuk sebagai slogan atau mencerminkan identitas kota agar lebih dikenal masyarakat tetapi branding tersebut harus disertai dengan implementasi komprehensif dengan programprogram yang memberikan dampak baik bagi kota Bandung. City branding tidak untuk merubah suatu kota akan tetapi dapat membantu meningkatkan kemajuan suatu kota seperti dapat meningkatkan bisnis investasi, posisi kompetitif kota dalam pasar pariwisata, dan pengembangan ekonomi sosial masyarakat kota.

\section{Pengaruh City Branding terhadap Image of Urban Destination}

Hasil perhitungan menunjukkan bahwa pengaruh city branding terhadap image of urban destination yaitu sebesar 0,637 atau 40,6\%. Hal ini bahwa semakin baik city branding Bandung, maka semakin tinggi pula Image of urban destination Bandung. Demikian pula sebaliknya bahwa semakin rendah Branding untuk kota Bandung, maka semakin rendah pula image bagi kota Bandung. Selain itu pula, penelitian ini mendukung penelitian sebelumnya, yakni Ratu Y. Chaerani (2011) yang menyatakan bahwa terdapat pengaruh signifikan antara city branding terhadap city image. Dengan demikian city branding berpengaruh secara langsung pada image of urban destination, yang berarti bahwa branding kota yang baik dan tepat sasaran maka akan meningkatkan atau memperbaiki image kota tersebut dan begitu juga sebaliknya. Karena pada dasarnya tujuan branding adalah untuk meningkatkan reputasi pemilikinya.

Hasil penelitian ini juga sejalan dengan penelitianpenelitian sebelumnya seperti yang dijelaskan oleh Anholt bahwa branding kota telah menjadi kegiatan yang umum termasuk untuk kepentingan sebuah daerah. Menurut Aaker (2012) mengemukakan merek yang kuat dapat membentuk sebuah citra. Termasuk city branding yang membentuk citra suatu tempat dan dari citra tersebut menghasilkan berbagai tanggapan dari penduduk, pengunjung, dan pebisnis terhadap 
suatu tempat. Sedangkan menurut Kavaratzis dan Ashworth (2005:507) membentuk city branding dapat mempengaruhi peta mental dengan kata lain bagaimana pengunjung mempersepsikan sebuah kota dibenak mereka. Komunikasi pemasaran dapat membantu untuk mengenalkan kota sebagai tujuan wisata atau lokasi investasi dengan meningkatkan persepsi positif orang tentang kota. Sesuai dengan peneltian Anholt terdapat enam komponen yang membentuk city branding yang harus diperhatikan oleh para pemasar yang terangkum dalam city brand hexagon yaitu presence (keberadaan), place (tempat), people (penduduk), pre-requisites (prasyarat), pulse (kemenarikkan), dan potential (potensi). Sedangkan citra destinasi merupakan gambaran pikiran, kepercayaan, perasaan, dan persepsi terhadap suatu destinasi (Fakeye dan Crompton dalam Chen (2007:1116). Terdapat dimensi dari citra destinasi menurut Hailin Qu et al. (2011:470), yaitu Cognitive destination image (citra destinasi kognitif), Unique destination image (citra destinasi yang unik), dan Affective destination image (citra destinasi afektif).

\section{Pengaruh City Branding terhadap Post-visit Behavior}

Hasil perhitungan menunjukkan bahwa pengaruh city branding terhadap post-visit behavior yaitu sebesar 0,584 atau sebesar $34,2 \%$. Nilai positif ini mengindikasikan bahwa semakin baik branding untuk kota Bandung, maka post-visit behavior wisatawan ke kota Bandung semakin baik. Demikian pula sebaliknya semakin rendah branding kota Bandung, maka post-visit behavior pun semakin rendah.

Hasil pengujian secara parsial tersebut didukung oleh Sri Utami et al. (2013) dalam penelitiannya menyebutkan bahwa nation branding berpengaruh signifikan terhadap proses keputusan wisatawan Australia ke Indonesia pada sub variabel yaitu culture dan heritage yang paling mempengaruhi proses keputusan untuk berkunjung, karena dalam proses keputusan untuk berkunjung terdapat dimensi perilaku pasca berkunjung. Maka jelaslah bahwa city branding merupakan faktor yang cukup berpengaruh terhadap post-visit behavior.

\section{Pengaruh Image of Urban Destination terhadap Post-Visit Behavior}

Berdasarkan hasil perhitungan menunjukkan pengaruh image of urban destination terhadap post-visit behavior yaitu sebesar 0,520 atau $27 \%$. Hal ini mengindikasikan bahwa semakin tinggi image dari kota Bandung, maka post-visit behavior wisatawan yang datang ke Bandung semakin tinggi pula dengan tingkat kepuasannya, bersedia untuk merekomendasikannya, dan kecenderungan untuk berkunjung kembali ke kota Bandung. Dan sebaliknya semakin rendah image terhadap kota Bandung, maka semakin rendah pula post-visit behavior mereka ke kota Bandung dengan menunjukkan ketidakpuasan, enggan untuk merekomendasikan dan enggan untuk datang kembali ke kota Bandung.

Hasil pengujian tersebut sejalan dengan penelitian yang dilakukan oleh Scoria Novrisa Dewi et al. (2013) yang meyimpulkan bahwa citra destinasi berpengaruh langsung terhadap perilaku pasca berkunjung. Berdasarkan pernyataan tersebut maka image of urban destination merupakan faktor yang mampu menentukan bagaimana perilaku pasca berkunjung wisatawan ke suatu destinasi. Karena image pada hakikatnya membentuk persepsi dibenak wisatawan yang dapat menyebabkan keputusan mereka untuk bertindak.

Penelitian ini juga mendukung pernyataan Chon's dalam Dewi et al. (2013:18) bahwa Cara pandang konsumen terdapat kaitannya antara citra destinasi dengan perilaku konsumen yang dikemukakan mengungkapkan bahwa citra destinasi berperan dan berpengaruh dalam perilaku pembelian dan kepuasan. Dijelaskan pula oleh Coshall dalam Dewi et al. (2013:17) menyatakan bahwa citra destinasi merupakan kesan wisatawan secara umum terhadap suatu destinasi wisata. Begitupun menurut Echtner dan Ritchie dalam Dewi (2013:17) mengungkapkan bahwa citra destinasi berperan penting dalam memahami perilaku wisatawan dalam melakukan perjalanan.

Penjelasan tersebut diperkuat bahwa citra destinasi memiliki pengaruh pada perilaku wisatawan yaitu mempengaruhi proses pengambilan keputusan pilihan tujuan menyangkut pengalaman selama perjalanan bagaimana kualitas perjalanan selama tinggal di suatu destinasi, nilai dan kepuasan secara keseluruhan, dan niat mengunjungi dan kesediaan untuk merekomendasikannya pada orang lain (Chen dan Tsai, 2007:1115). Kota yang memiliki citra destinasi positif akan menyebabkan tingkat kepuasan lebih besar dan berpotensi pada minat perilaku wisatawan terhadap destinasinya. 


\section{Pengaruh City Branding terhadap Post-Visit Behavior melaui Image of Urban Destination}

Hasil perhitungan menunjukkan bahwa pengaruh tidak langsung antara city branding terhadap post-visit behavior melalui image of urban destination adalah sebesar 0,331 sedangkan nilai variabel city branding terhadap post-visit behavior memiliki hubungan secara langsung sebasar 0,584. Sehingga dapat disimpulkan bahwa nilai hubungan secara langsung lebih besar daripada hubungan tidak langsung untuk variabel city branding Bandung terhadap post-visit behavior wisatawan ke kota Bandung melalui image of urban destination atau $0,584>0,331$. Artinya, variabel image of urban destination belum tentu dapat memperkuat hubungan antara variabel city branding dengan post-visit behavior. Dengan demikian variabel image of urban destination memiliki peran yang kecil sebagai variabel intervening, namun sebuah image tetap dibutuhkan dalam mengambil sebuah keputusan.

Hasil ini sejalan Cavia Fernandez et al. (2013:624) menjelaskan Branding tidak dipandang sebagai cara untuk mengelola suatu kota, melainkan dipandang sebagai alat untuk menyampaikan citra positif yang bertujuan untuk meningkatkan persepsi yang dimiliki oleh berbagai pemangku kepentingan, dimana branding tidak dapat merubah suatu kota tetapi tetapi dapat membantu meningkatkan daya saing secara keseluruhan. Jika city branding mampu membentuk citra positif dibenak wisatawan maka akan mempengaruhi cara perilaku wisatawan sebelum, sesudah, dan setelah mengunjungi suatu destinasi. Hal ini dipertegas oleh Theodhori dan Quirici (2014:24) dalam penelitiannya mempromosikan nation branding bertujuan untuk meningkatkan citra yang membedakan dirinya dari para pesaing karena globalisasi serta memiliki dampak yang besar terhadap perilaku wisatawan untuk mengeksplorasi destinasi.

Rekomendasi yang dapat ditarik dari hasil penelitian ini bahwa untuk memperkenalkan kota Bandung dan meningkatkan reputasi terhadap wisatawan salah satunya dengan melakukan penetapan brand bagi kota Bandung dengan didasarkan pada keunggulan potensi yang dimiliki agar tujuannya dapat tercapai yang tentunya untuk mempengaruhi persepsi wisatawan terhadap kota Bandung baik pada saat wisatawan belum atau setelah mengunjungi kota Bandung. Pada akhirnya wisatawan akan melakukan evaluasi terhadap keputusannya terutama setelah mereka berkunjung ke kota Bandung, baik itu meliputi kepuasan setelah berkunjung, berkeinginan untuk merekomendasikan, maupun kecenderungan untuk berkunjung kembali.

\section{KESIMPULAN}

Berdasarkan pembahasan tersebut dapat ditarik kesimpulan yaitu bahwa untuk memperkenalkan kota Bandung dan meningkatkan reputasi terhadap wisatawan salah satunya dengan melakukan penetapan brand bagi kota Bandung dengan didasarkan pada keunggulan potensi yang dimiliki agar tujuannya dapat tercapai yang tentunya untuk mempengaruhi persepsi wisatawan terhadap kota Bandung baik pada saat wisatawan belum atau setelah mengunjungi kota Bandung. yang pada akhirnya wisatawan akan melakukan evaluasi terhadap keputusannya terutama setelah mereka berkunjung ke kota Bandung, baik itu meliputi kepuasan setelah berkunjung, berkeinginan untuk merekomendasikan, maupun kecenderungan untuk berkunjung kembali.

Berdasarkan hasil penelitian yang dilakukan, masih terdapat kekurangan dalam setiap aspek dari variabel yang diteliti yaitu mengenai kemudahan dalam menjangkau objek wisata, kualitas infrastruktur yang tersedia, dan penyediaan transportasi lokal dikota Bandung. Sebaiknya pemerintah menyediakan fasilitas dasar bagi kebutuhan wisatawan seperti memberikan petunjuk jalan yang lebih terarah atau menyediakan rute cadangan perjalanan wisata yang dikemas lebih kreatif, maupun buku petunjuk objek wisataagar wisatawan dapat dengan mudah menjangkau objek wisata tersebut, kemudian pemanfaatan lahan kosong untuk dijadikan fasilitas umum, dan perbaikan berkelanjutan mengenai kondisi jalan raya yang kurang baik serta kebijakankebijakan yang memberikan kenyamanan bagi setiap pemangku kepentingan termasuk wisatawan, dan menyediakan sarana transportasi yang disediakan untuk wisatawan.

Terlihat pada variabel city branding dengan rata sebesar 3,742. Hal ini menjelaskan bahwa kota Bandung pantas menjadi kota kreatif. Maka untuk penetapan brand kota yang menjadi identitas kota Bandung sebagai kota kreatif dapat di implementasikan. Kemudian pada variabel image of urban destination dengan rata-rata sebesar 3,87 yang berarti bahwa 
image kota Bandung masih dipersepsikan memiliki image yang positif sehingga image ini baik bagi kota Bandung dan bisa mendukung dalam penetapan city branding Bandung sebagai kota kreatif. Selanjutnya variabel post-visit behavior dengan indeks ratarata sebesar 3,55. Hal ini mengindikasikan bahwa wisatawan yang telah berkunjung ke kota Bandung berperan baik sebagai media komunikasi yang membantu memperkenalkan kota Bandung pada audiens eksternal untuk berkunjung ke kota Bandung.

\section{DAFTAR PUSTAKA}

Anholt, Simon. 2006. The Anholt - GMI City Brands Index: How The World Sees The World's Cities? Place Branding. 2(1): 18-31.

Chen, Ching-fu \& Dung Chun Tsai. 2007. How Destination Image and Evaluative Factors Affect Behavioral Intentions?. Journal Tourism Management. 28(4): 1115-1122.

Dinas Kebudayaan dan Pariwisata. 2013. Data Kunjungan Wisatawan yang Datang ke Kota Bandung tahun 2008-2013. Bandung: Disbudpar.

Echtner, Charlotte \& Brent Ritchle. 2003. The Meaning and Measurement of Destination Image. Journal of Tourism Studies. 14(1): 37-48.

Fernandez-Cavia, Jose et al. 2013. Destination Brands and Website Evaluation: a Research Methodology. Revista Latina de Comunicacion Social. 68: 622638.

Juanim. 2004. Analisis Jalur dalam Riset Pemasaran. Bandung: Universitas Pasundan.

Kotler, Philip \& Kevin Lane Keller. 2012. Marketing Management $\left(14^{\text {th }}\right.$ edition). New Jersey: Prentice Hall.
Kowalik, Izabela. 2012. Influence of Trade Fairs on a Host City Brand. Public Policy and Administration Journal. 11(4): 629-640.

Mihalis, Kavaratzis \& Ashworth G. J. 2005. City Branding: An Effective Assertion of Identity or a Transitory Marketing Trick?. Tijdschrift Voor Economische en Sociale Geografie. 96(5): 506-514.

Murfianti, Fitri. 2010. Membangun City Branding Melalui Solo Batik Carnival. Jurnal Penelitian Seni Budaya. 2(1): 14-20.

Riduwan dan Engkos A. Kuncoro. 2013. Path Analysis (Cara Menggunakan dan Memaknai Analisis Jalur). Bandung: Alfabeta.

Scoria, Novrisa Dewi et al. 2013. Pengaruh Citra Destinasi Pariwisata Kabupaten Belitung terhadap Perilaku Pasca Berkunjung Wisatawan Nusantara. Tourism and Hospitality Essential Anthology. 1(Desember): 1-8.

Sugiarsono, Joko. 2009. Bukan Asal Membuat Logo dan Slogan. Swa Sembada. http://202.59.162.82/ swamajalah/sajian/details.php?cid=1\&id=9595.

Sugiyono. 2012. Metode Penelitian Bisnis. Bandung: Alfabeta

Theodhori, Oriole \& Eleina Qirici. 2014. The Impact of Destination Branding to Tourists Behavior Albania in Focus. Journal of Knowledge Management, Economics and Information Technology. 4(1): 1925.

Qu, Hailin et al. 2011. A Model of Destination Branding: Integrating the Concepts of the Branding and Destination Image. Journal of Tourism Management. 32: 465-476.

Yuli, Aditya. 2011. City Branding Sebagai Strategi Pengembangan Pariwisata Ditinjau dari Aspek Hukum Merek. Jurnal Ilmiah Ilmu Hukum QISTI. 5(1): 50-68. 